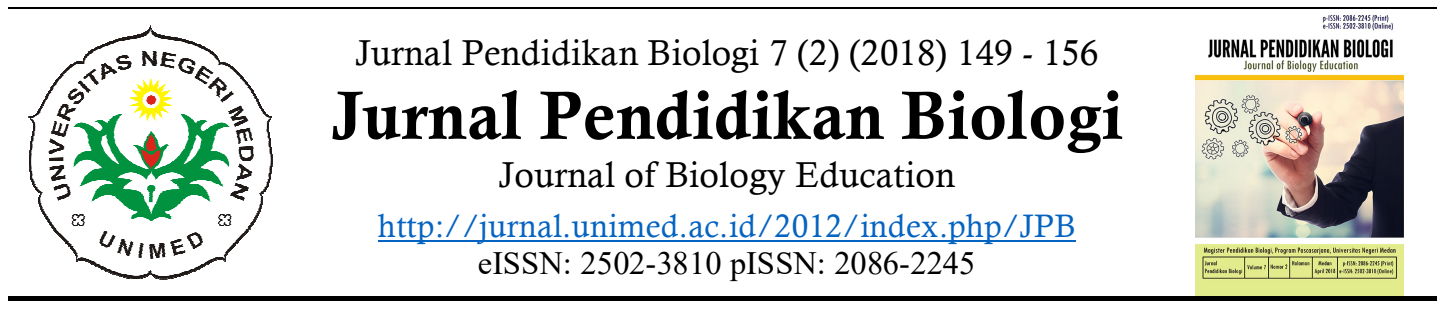

\title{
Metode Demonstrasi dan Penugasan Terhadap Kemampuan Mendeskripsikan Hubungan Antara Ciri Khusus Mahluk Hidup Terhadap Lingkungan Hidupnya pada Siswa Kelas 5
}

\author{
Adriyawati $^{1, \bullet}$, Syarif Sumantri ${ }^{2}$, Indina Tarjiah ${ }^{2 \bullet \bullet}$ \\ ${ }^{1}$ Program Studi Pendidikan Dasar, Fakultas Ilmu Pendidikan, Universitas Negeri Jakarta \\ ${ }^{2}$ Program Studi, Pendidikan Luar Biasa, Fakultas Ilmu Pendidikan, Universitas Negeri \\ Jakarta \\ Korespondensi: “adriyawati9@gmail.com, ${ }^{\cdots}$ indina.tarjiah@gmail.com
}

DOI: https://doi.org/10.24114/jpb.v7i2.10061

\begin{abstract}
This action research was carried out to find out the improvement of learning by using Classroom Action Research which was carried out by using visual aids about living creatures, animal and plant props such as lizard, embarrassed daughter leaves, cocor duck in the students' environment. The method used in this study is action research developed by John Elliot's Model. Actions in this study were carried out in 2 cycles. Each cycle consists of planning, action, observation and reflection. The subject of this learning improvement study is the children of SDN Karang Satria 05, District of North Tambun, Bekasi Regency. Data analysis used in this study was carried out by means of quantitative and qualitative approaches. Quantitative analysis shows an increase in interpersonal intelligence from pre-research to cycle 2 , which is $86 \%$. Based on the agreement of researchers with collaborators, the success of the action can occur if there is an increase in students' ability in describing the relationship between the special characteristics of living creatures to the environment reaching $71 \%$. this, the improvement of learning outcomes and the ability to describe the relationship between the special characteristics of living beings to the environment has succeeded in surpassing $71 \%$. The results showed that the application of demonstration methods and assignments could improve learning outcomes and students' ability in describing the relationship between the special characteristics of living beings to the environment. this can be seen from changes in children's attitudes before using demonstration methods and assignments.
\end{abstract}

Keyword: Learning Outcomes, Assignment Demonstrations, Describing Abilities

\section{PENDAHULUAN}

Pembelajaran yang berhasil ditentukan oleh adanya perubahan dari peserta didik, seperti dari tidak mengerti menjadi mengerti atau dari tidak bisa menjadi bisa. Perubahan ini memiliki arti dapat menumbuh kembangkan potensi-potensi yang dimiliki peserta didik sehingga peserta didik menikmati manfaatnya secara langsung dalam upaya mengembangkan pribadinya menjadi lebih berkualitas (Sauri, 2010). Tanggung jawab dari keberhasilan pembelajaran utamanya berada di tangan seorang guru sebagai pendidik. Artinya, pendidik dituntut berupaya secara optimal 
mengatur proses pembelajaran sedemikian rupa sehingga komponen-komponen yang diperlukan dapat bersinergi untuk mencapai tujuan pembelajaran yang diharapkan. Pembelajaran menurut Sagala (2010) merupakan suatu sistem yang tersusun dari manusiawi, material, fasilitas, perlengkapan, dan prosedur yang saling mempengaruhi pencapaian tujuan pembelajaran. Manusia yang terlibat dalam pembelajaran terdiri dari peserta didik, guru dan tenaga kependidikan lainnya. Material pendukung pembelajaran seperti buku-buku, papan tulis, fotografi, slide, film, audio, gambar, dan vidio tape serta material lainnya. Fasilitas pendukung pembelajaran, seperti ruang kelas, perlengkapan audio visual, juga komputer. Sedangkan prosedur,meliputi jadwal dan metode penyampaian informasi, praktek, belajar, dan evaluasi.

Dalam upaya mengaktifkan fungsifungsi pendidikan sebagai salah satu cara dalam mengembangkan pribadi peserta didik dari yang belum tahu menjadi tahu. Murwani (2006) mengemukakan implikasinya bagi tugas dan peran yang harus dijalankan oleh guru, yaitu (a) Konservator/pemelihara sistem nilai yang merupakan nilai ilmu pengetahuan (b) Trasmitor/penerus sistem nilai tersebut kepada sasaran didik, (c) Transformator/penerjemah dengan memberi contoh dan memeragakan sistem nilai tersebut dalam berinteraksi dengan peserta didiknya, (d) Organisator/penyelenggara pendidikan dengan menciptakan lingkungan pembelajaran yang kondusif bagi peserta didiknya dan dapat dipertanggungjawabkan baik secara profesional, intelektual, maupun secara moral kepada peserta didik, orang tua/masyarakat dan kepada Tuhan Yang Maha Esa. Sebagai organisator pendidikan di kelas, sudah selayaknya guru dapat memecahkan permasalahan yang timbul dengan melakukan pengamatan dan penelitian munculnya persoalan rendahnya tingkat penguasaan materi peserta didik (Hasyim, 2014).

Dalam Mata Pelajaran Ilmu Pengetahuan Alam bagi peserta didik biasanya terasa membosankan karena kebanyakan guru menerapkan metode ceramah untuk mentransfer konsep-konsep materi kepada peserta didiknya. Hal ini tentunya membuat peserta didik cenderung bosan dan tidak menarik perhatian peserta didik untuk belajar. Diperlukan inovasi pembelajaran bagi guru di kelas. Salah satunya dengan penggunaan media pembelajaran yang tepat dalam mengajarkan suatu konsep-konsep Ilmu Pengetahuan Alam.

Setelah melakukan pengamatan dan berdasarkan hasil belajar siswa, penerapan penggunaan alat peraga di kelas dalam menyampaikan materi pembelajaran terasa sangat kurang dioptimalkan guru kelas $\mathrm{V}$ SDN Karang Satria 05, khususnya dalam peninkatan hasil belajar dan kemampuan mendiskripsikan hubungan antara ciri-ciri khusus mahluk hidup terhadap lingkungan hidupnya.

Hal ini dibuktikan dari rendahnya tingkat pemahaman peserta didik setelah menerima materi, pembelajaran dimana, hasil belajar rata-rata di kelas tidak memuaskan, Media pembelajaran terkesan seadanya dalam mendukung ketercapaian pemahaman peserta didik pada konsepkonsep Ilmu Pengetahuan Alam. Keterampilan guru dalam memanfaatkan media pembelajaran yang terbatas. Rasa enggan guru dalam berkolaborasi dengan teman sejawat dalam memecahkan permasalahan pembelajaran terutama dalam penyediaan media pembelajaran sederhana yang mudah, murah, serta tepat. Metode pembelajaran yang ditampilkan guru kurang tepat bahkan cenderung membosankan bagi peserta didik dengan 
konsep yang diajarkan.Untuk meningkatkan penguasaan peserta didik terhadap materi dimaksud, diperlukan perbaikan pembelajaran melalui Penelitian Tindakan Kelas (Classroom Action Recearch) yang dilakukan sebelum proses pembelajaran melalui persiapan, selama proses kegiatan belajar dengan adanya pengamatan dan observasi serta setelah pembelajaran berlangsung dengan melakukan refleksi diri tentang kelemahan yang mungkin muncul dari proses pembelajaran yang telah dilakukan. Upaya yang ditempuh melalui penggunaan media pembelajaran yang terdekat dengan lingkungan peserta didik sehingga hasil yang diharapkan adalah terjadinya pembelajaran yang akif, kreatif, efektif, dan menyenangkan serta hasil belajar yang sesuai dengan tujuan pembelajaran (Setyosari, 2016).

Berdasarkan masalah tersebut, tujuan penelitian ini adalah menganalisis hubungan Metode penugasan untuk meningkatkan hasil belajar dan kemampuan mendeskripsikan hubungan antara ciri khusus mahluk hidup terhadap lingkungan hidupnya".

\section{METODE PENELITIAN}

Penelitian ini dilaksanakan Di SDN Karang Satria 05 pelaksanaan penelitian dilaksanakan pada tanggal 28 April sampai 31juni tahun 2018 menggunakan metode penelitian tindakan yang difokuskan pada situasi kelas, atau lazim dikenal dengan classroom action research (penelitian tindakan kelas) (Kemmis dan McTaggart, 2005).
Penelitian ini dimulai dengan pencarian informasi data data yang diperlukan . Temuan dari hasil pencarian infomasi ini kemudian refleksi bersama antara peneliti dengan guru untuk menentukan langkah-langkah kegiatan selanjutnya (tindakan, observasi dan penyusunan rencana ulang) Rancangan desain penelitian yang akan dilakukan dikembangkan dari PTK model Jhon Elliot (Elliot, 1991) Model ini lebih menekankan pada proses untuk mencoba hal-hal yang baru dalam proses pembelajaran, langkah pertama yang harus dilakukan adalah menentukan dan mengembangkan gagasan umum yang dilanjutkan dengan melakukan eksplorasi yakni untuk mempertajam gagasan atau ide mengenai model PTK bahwa apapun masalah yang akan diangkat dalam penelitian hendaknya tetap berada dalam lingkup permasalahan yang dihadapi oleh guru didalam pelaksanaan pembelajaran sehari-hari di kelas dan merupakan sesuatu yang ingin diperbaiki atau diubah.

Penelitian Tindakan Kelas ini direncanakan pelaksanaannya dalam tiga siklus yang berkelanjutan untuk konsep hubungan antara ciri khusus mahluk hidup dan lingkungan hidupnya. Setiap siklus penelitian dilaksanakan dengan langkahlangkah perencanaan, pelaksanaaan tindakan, pengamatan (observasi) dan refleksikemudian di observasi melalui pengamatan hasil observasi tersebut kemudian di refleksi untuk mengambil tindakan selanjutnya apabila belum berhasil apabila berhasil maka penelitian tidak di lanjutkan. 


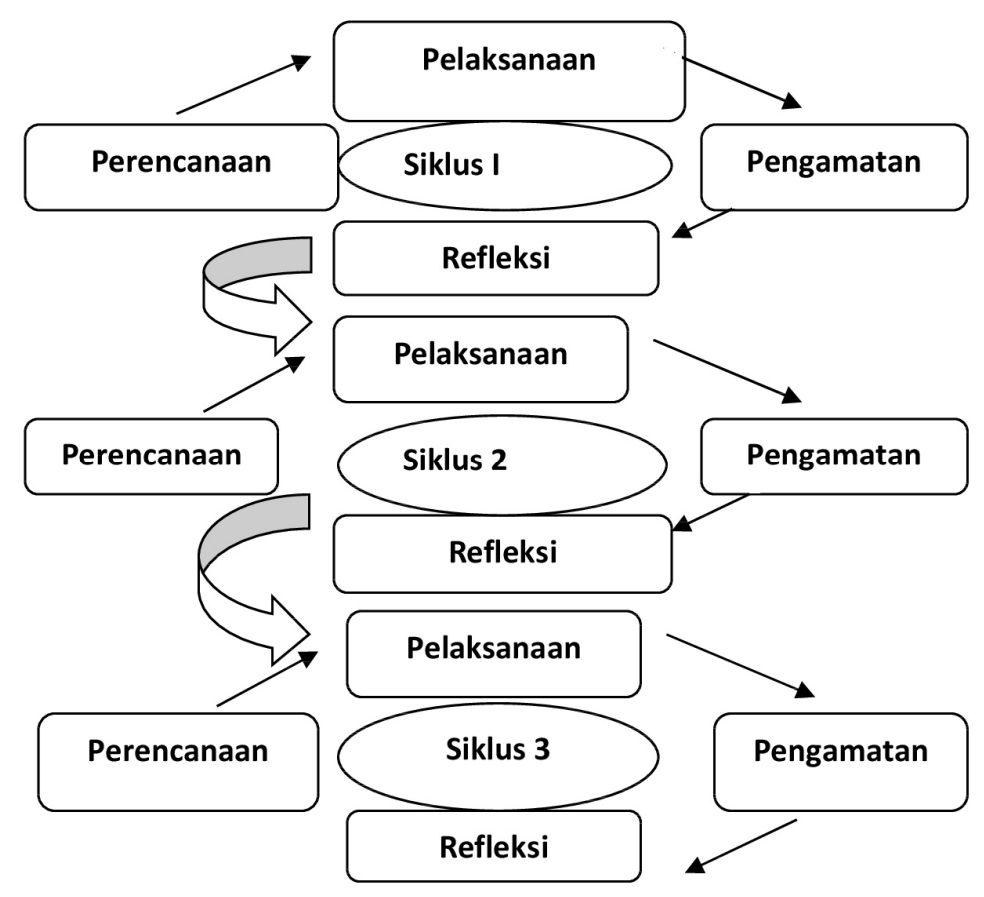

Gambar 1. Riset Aksi Model John Elliot (Elliot, 1991)

\section{Desain Tindakan Kelas}

Penelitian ini dilakukan dengan 2 siklus, pada siklus pertama memilih pendekatan, metode, dan keterampilan mengajar yang tepat sehingga peserta didik lebih memahami indikator mengidentifikasi Gambar tentang mahluk hidup hewan dan tumbuhan, alat peraga hewan dan tumbuhan seperti cicak, daun putri malu, cocor bebek. Menyusun alat evaluasi belajar untuk melihat kemampuan peserta didik dalam memahami mengidentifikasi Gambar tentang mahluk hidup hewan dan tumbuhan, alat peraga hewan dan tumbuhan seperti cicak, daun putri malu, cocor bebek yang berhubungan dengan lingkungan hidupnya. Pada siklus kedua Memilih pendekatan, metode, dan keterampilan mengajar yang tepat sehingga peserta didik lebih memahami mendeskripsikan hubungan antara ciri khusus mahluk hidup dan lingkungan hidupnya. Menyusun alat evaluasi belajar untuk melihat Hasil Belajar dan kemampuan peserta didik dalam mendeskripsikan hubungan antara ciri khusus mahluk hidup terhadap lingkungan hidupnya.

\section{Kriteria Keberhasilan Tindakan}

Berdasarkan kesepakatan dalam penelitian ini apabila Hasil Belajar dan kemampuan mendikrisiikan hubungan antara ciri khusus mahluk hidup terhadap lingkungannya pada Peserta didik dapat meningkat melalui metode demonstrasi serta penugasan sebesar $71 \%$. Jika hasil tindakan sudah mencapai target yang telah di tentukan maka penelitian ini selesai dan tidak di lanjutkan ke siklus berikutnya.

\section{Sumber Data}

Subjek penelitian perbaikan pembelajaran ini adalah Peserta Didik 
SDN Karang Satria 05 Kecamatan Tambun Utara Kabupaten Bekasi, pada kelas V A yang berjumlah 31 peserta didik, terdiri dari
13 peserta didik laki-laki dan 18 peserta didik perempuan, pada pelajaran IPA.

Tabel 1. Kisi-Kisi Instrumen dan Validasi Instrumen

\begin{tabular}{llc}
\hline \multicolumn{1}{c}{ Variabel } & \multicolumn{1}{c}{ Indikator } & Teknik Penilaian \\
\hline $\begin{array}{l}\text { Mendeskripsikan } \\
\text { Kubungan antara Ciri }\end{array}$ & $\begin{array}{l}\text { Mengidentifikasi Gambar tentang mahluk } \\
\text { hidup hewan dan tumbuhan, alat peraga } \\
\text { ndan }\end{array}$ hahluk Hidup & Observasi \\
hidupnya & Lingkungan dan tumbuhan seperti cicak, daun & \\
& mendri malu, cocor bebek. & \\
& khusus mahluk hidup dan lingkungan & Observasi \\
hidupnya & \\
\hline
\end{tabular}

Subjek penelitian perbaikan pembelajaran ini adalah Peserta Didik SDN Karang Satria 05 Kecamatan Tambun Utara Kabupaten Bekasi, pada kelas V A yang berjumlah 31 peserta didik, terdiri dari 13 peserta didik laki-laki dan 18 peserta didik perempuan, pada pelajaran IPA.

\section{Kisi-Kisi Instrumen dan Validasi Instrumen}

Validasi instrumen yang di gunakan dalam penelitian ini adalah instumen rancangan peneliti. Oleh sebab itu perlu di lakukan uji coba instrument untuk mengukur validitas instrument.

\section{Teknik Pengumpulan Data dan Validasi Data}

Teknik pengumpulan data dalam penelitian ini adalah melalui observasi dan studi domentasi. Observasi atau pengamatan adalah suatu teknik yang dilakukan dengan cara mengadakan pengamatan secara pencatatan dan secara sistematis. Observasi dengan cara untuk mengumpulkan data dari objek penelitian, yang dilakukan langsung terhadap siswa untuk mengetahui apakah dengan menggunakan metode demostrasi dan penugasan dapat Meningkatkan Hasil Belajar dan Kemampuan Peserta Didik dalam Mendeskripsikan Hubungan antara Ciri Khusus Mahluk Hidup terhadap Lingkungan Hidupnya.

Hasil belajar anak didik Kelas V SDN Karang Satria 05 Kec.Tambun Utara Kab.Bekasi diukur dengan menggunakan lembar observasi dan lembar tugas anak. Hasil belajar berupa lembar observasi dilakukan guru pada saat proses pembelajaran berlangsung dengan cara mengamati sikap dan perilaku anak selama proses pembelajaran berlangsung.

Lembar tugas digunakan untuk mengetahui kemampuan anak pada kegiatan membaca. Indikator yang digunakan adalah sebagai berikut: (1) Mengidentifikasi Gambar tentang mahluk hidup hewan dan tumbuhan, alat peraga hewan dan tumbuhan seperti cicak, daun putri malu, cocor bebek. (2) mendeskripsikan hubungan antara ciri khusus mahluk hidup dan lingkungan hidupnya.

Validitas ini didasarkan pada kepastian apakah hasil penelitian sudah akurat dari sudut pandang peneliti, partisipan, atau pembaca secara umum (Ceswell \& Miller, 2000). Moleong (2006) mengemukakan bahwa "Untuk keperluan itu teknik ini menuntut agar peneliti mampu menguraikan secara rinci bagaimana proses 
penemuan secara kualitatif dan penelaahan secara rinci tersebut dapat dilakukan. Dengan demikian pengolahan data melalui validitas data agar dapat dikaji untuk mengurai secara rinci dari proses observasi, wawancara, dan dokumentasi dari subjek penelitian.

\section{Tehnik Analisis Data}

Analisis Data hasil belajar siswa berupa skor yang diperoleh dari tes yang telah dilakukan, dengan rincian: (1) Nilai Rata - rata Persiklus dapat dirumuskan: Average $\sum$ Jumlah Semua Nilai siswa. (2)Nilai persentase ketuntasan belajar digunakan rumus sebagai berikut: siswa yang tuntas/belum tuntas belajar $\sum$ siswa $\mathrm{x}$ $100 \%$.

Hasil dari penghitungan di atas dapat diketahui kriteria kemampuan anak di dalam pembelajaran melalui metode demostrasi dan penugasan dalam upaya Upaya Meningkatkan Hasil belajar dan Kemampuan Peserta Didik dalam Mendeskripsikan Hubungan antara Ciri Khusus Mahluk Hidup ndan Lingkungan Hidupnya. Penelitian ini untuk mengetahui tingkat penguasaan metode pembelajaran, hasil penilaian kemampuan anak dalam bentuk persentase..

\section{HASIL DAN PEMBAHASAN}

\section{Data Deskripsi Pra Penelitian (Pra Siklus)}

Dari hasil kegiatan penelitian tindakan kelas dalam pembelajaran yang dilakukan di kelas V SDN Karang Satria 05 semester I, terlihat pada awalnya sebagian besar peserta didik belum dapat memahami tentang deskripsi hubungan antara ciri-ciri khusus mahluk hidup dan lingkungan hidupnya.

Tabel 2. Analisis Nilai Prasiklus

\begin{tabular}{ccc}
\hline Nilai & Banyak siswa & Presentase \\
\hline 10 & - & - \\
20 & - & - \\
30 & - & - \\
40 & 4 & $12,90 \%$ \\
50 & 3 & $9,67 \%$ \\
60 & 12 & $38,70 \%$ \\
70 & 9 & $29,00 \%$ \\
80 & 3 & $9,67 \%$ \\
90 & - & - \\
100 & - & - \\
Total & $\mathbf{3 1}$ & $\mathbf{1 0 0} \%$ \\
\hline
\end{tabular}

Dari Tabel 2, analisis nilai siswa yang tuntas $38,71 \%$ dengan jumlah 12 siswa dan yang belum tuntas $61,29 \%$ dengan jumlah 19 siswa. Pada pra siklus ini sebagian besar peserta didik belum dapat memahami tentang deskripsi hubungan antara ciri-ciri khusus mahluk hidup dan lingkungan hidupnya.

\section{Deskripsi Data dan Hasil Tindakan Siklus} I

Dalam siklus pertama peneliti Memilih pendekatan, metode, dan keterampilan mengajar yang tepat sehingga peserta didik lebih memahami indikator mengidentifikasi Gambar tentang mahluk hidup hewan dan tumbuhan, alat peraga hewan dan tumbuhan seperti cicak, daun putri malu, cocor bebek. Pada kegiatan inti yaitu (1) peserta didik menyimak penjelasan guru tentang deskripsi mahluk hidup (2) 
mendeskripsikan hubungan antara ciri-ciri khusus mahluk hidup dan lingkungan hidupnya. (3) peserta didik mngerjakan soal-soal latihan.

Tabel 3. Analisis Nilai Siklus 1

\begin{tabular}{ccc}
\hline Nilai & Banyak siswa & Presentase \\
\hline 10 & - & - \\
20 & - & - \\
30 & - & - \\
40 & - & - \\
50 & 5 & $16,13 \%$ \\
60 & 8 & $25,80 \%$ \\
70 & 5 & $16,13 \%$ \\
80 & 7 & $22,59 \%$ \\
90 & 6 & $19,35 \%$ \\
100 & - & - \\
Total & 31 & $\mathbf{1 0 0} \%$ \\
\hline
\end{tabular}

Dari Tabel 3 presentase nilai siswa yang tuntas $58,06 \%$ dengan jumlah 18 siswa dan yang belum tuntas $41,93 \%$ dengan jumlah 13 siswa. pada siklus I, yaitu siswa masih kurang maksimal dalam penguasaan materi pelajaran. Hal tersebut karena pada proses kegiatan pembelajaran terjadi hal-hal sebagai berikut: (1) Kegiatan pembelajaran terliahat monoton dan pasif (2) Pola interaksi guru dan peserta didik condong searah (3) Beberapa peserta didik tidak memperhatikan. (4) Tidak munculnya motivasi belajar peserta didik yang merasa jenuh dengan interaksi pembelajaran di kelas.

\section{Deskripsi Data Siklus II}

Dalam siklus kedua peneliti Memilih pendekatan, metode, dan keterampilan mengajar yang tepat sehingga peserta didik lebih memahami mendeskripsikan hubungan antara ciri khusus mahluk hidup dan lingkungan hidupnya, pada kegiatan inti yaitu (1) peserta didik menyimak penjelasan guru tentang mendeskripsikan hubungan antara ciri-ciri khusus mahluk hidup dan lingkungan hidupnya. (2) guru mengarahkan peserta didik untuk mengamati alat peraga hewan dan tumbuhan seperti cicak, daun putri malu, cocor bebek yang berhubungan dengan lingkungan hidupnya.

Tabel 4. Hasil Analisis Nilai Siklus 2

\begin{tabular}{ccc}
\hline Nilai & Banyak Siswa & Presentase \\
\hline 10 & - & - \\
20 & - & - \\
30 & - & - \\
40 & - & - \\
50 & 1 & $3,22 \%$ \\
60 & 1 & $3,22 \%$ \\
70 & 5 & $16,13 \%$ \\
80 & 6 & $19,36 \%$ \\
90 & 10 & $32,26 \%$ \\
100 & 8 & $25,81 \%$ \\
Total & $\mathbf{3 1}$ & $\mathbf{1 0 0 \%}$ \\
\hline
\end{tabular}


Dari Tabel 4, Persentase nilai siswa yang tuntas 93,54\% dengan jumlah 29 siswa dan yang belum tuntas $6,45 \%$ dengan jumlah 2 siswa siklus kedua ini sudah terlihat peningkatan prestasi belajar peserta didik, karena dalam pembelajaran guru menggunakan media langsung atau hewan dan tumbuhan seperti cicak, daun putri malu, cocor bebek yang séungguhnya. Suasana kelas menjadi aktif karena hampir seluruh peserta didik terlibat dalam proses pembelajaran secara aktif karena mendapat stimulus berupa media yang menarik minat peserta didik untuk belajar. Hasil refleksi sudah mencapai tujuan yang hendak dicapai sehingga dirasa tidak perlu melakukan perbaikan pada siklus ketiga. Menurut Aprilia dan Kristanto (2016), metode penugasan dan demonstrasi kurang mengembangkan kemampuan sains anak.

\section{KESIMPULAN}

Berdasarkan hasil pentlitian dapat disimpulkan bahwa presentase nilai siswa yang tuntas $58,06 \%$ dengan jumlah 18 siswa dan yang belum tuntas 41,93\% dengan jumlah 13 siswa pada siklus I. Persentase nilai siswa yang tuntas pada siklus II adalah 93,54\% dengan jumlah 29 siswa dan yang belum tuntas $6,45 \%$ dengan jumlah 2 siswa siklus kedua ini sudah terlihat peningkatan prestasi belajar peserta didik. Hasil penelitian menunjukkan bahwa penerapan metode dan penugasan demonstrasi dapat meningkatkan hasil belajar dan kemampuan siswa dalam menjelaskan hubungan antara karakteristik khusus makhluk hidup dengan lingkungan

\section{DAFTAR PUSTAKA}

Aprilia, S. dan Kristanto, A (2016). Pengaruh metode inkuiri terhadap kemampuan sains anak kelompok B. Jurnal PAUD Teratai, 5(2): 44-48.

Creswell, J. W., \& Miller, D. L. (2000). Determining validity in qualitative inquiry. Theory into practice, 39(3), 124-130.

Elliot, J. (1991). Action research for educational change. McGraw-Hill Education (UK).

Hasyim, M. H. M. (2014). Penerapan fungsi guru dalam proses pembelajaran. AULADUNA: Jurnal Pendidikan Dasar Islam, 1(2), 265-276.

Kemmis, S., \& McTaggart, R. (2005). Participatory action research: Communicative action and the public sphere. Sage Publications Ltd.

Moleong, L.J. (2006). Metodologi Penelitian Kualitatif. PT Remaja Rosdakarya, Bandung.

Murwani, E.D. (2006). Peran Guru dalam Membangun Kesadaran Kritis Siswa. Jurnal Pendidikan Penabur, 6(5), pp. 59-68.

Sagala, S. (2010). Konsep dan Makna Pembelajaran. Alfabeta, Bandung.

Sauri, S. (2010). Membangun Karakter Bangsa Melalui Pembinaan Profesionalisme Guru Berbasis Pendidikan Nilai. Jurnal Pendidikan Karakter, 2(2).

Setyosari, H.P. (2016). Metode Penelitian Pendidikan \& Pengembangan. Prenada Media. 